\title{
Çoban Çalışanların Çalışma Şartlarının İş Hukuku Açısından Değerlendirilmesi: Atyolu Köyü Örneği
}

\section{Evaluation of the Working Conditions of Herd Employees in Terms of Labor Law: The Example of Atyolu Village}

\author{
Hayrettin Şahin ${ }^{1} \odot$ Kemal Çiftyıldız ${ }^{2} \odot$ Cemile Evkaya $^{3} \odot$
}

\section{Öz}

Hayvancılıkla uğraşıp aynı zamanda bölgenin çoban ihtiyacını büyük ölçüde gideren Erzurum Illi Şenkaya İlçesi Atyolu Köyü'nün çoban çalışanları araştırmanın konusudur. Mevsimsel olarak göç edip çoban olarak çalışan bu köylülerin çalışma hayat ile ilgili veriler elde edilmeye çalışımıştır. Araştırmada katılımcı gözlem yöntemi kullanılarak veriler elde edilmiştir. İş hukuku açısından önem arz eden çalışma saatleri, izinler, çalışanların işverene karşı sorumlulukları ve hakları ele alınmaktadır. Diğer yandan temel yaşam gereksinimleri açısından önem arz eden beslenme, giyinme ve barınmalarına yönelik te araştırma yapılmıştır. Araştırmanın sonuçlarına göre iş kanununa uygun olmayan çalışma saatleri, izinler, kayıt dışı çalışılması, sosyal güvenlik kaydının bulunmaması en önemli sorunlarını teşkil etmektedir. Aynı zamanda, temel yaşam gereksinimlerinde de birçok eksiklikler olduğu tespit edilmiştir.

\section{Anahtar Kelimeler}

Çalışma hayatı • Çobanlık mesleği • Çoban çalışma hayatı • Atyolu, Şenkaya

\begin{abstract}
The topic of the research is animal husbandry in village of Atyolu in the district of Senkaya Erzurum regarding connection with the need of shepherds working in the region. The working life conditions of villagers who are seasonal immigrants have been observed. In the study data was collected through observation methods. Working hours, compensatory leave, responsibilities and rights of employers which are very important in labor law were all considered in the study. Furthermore the research was carried out on nutrition, clothing and shelter all of which are significant in terms of basic life necessities. According to the results of the survey,
\end{abstract}

\footnotetext{
1 Sorumlu Yazar: Hayrettin Şahin, (Dr. Öğr. Üyesi), Ağrı İbrahim Çeçen Üniversitesi, İktisadi ve İdari Bilimler Fakültesi, Siyaset Bilimi ve Kamu Yönetimi Bölümü, Ağrı Türkiye. Eposta: sahinhayrettin@gmail.com ORCID: 0000-0001-8921-2840

2 Kemal Çiftyıldız (Dr. Öğr. Üyesi), Bandırma Onyedi Eylül Üniversitesi, Manyas Meslek Yüksek Okulu, Mülkiyeti Koruma ve Güvenlik Bölümü, Balıkesir Türkiye. Eposta: kemalciftyildiz@gmail.com ORCID: 0000-0002-0204-6868
}

3 Cemile Evkaya (Doktora Öğrencisi), Sakarya Üniversitesi, Siyasal Bilgiler Fakültesi, Çalışma Ekonomisi ve

Atıf: Sahin, H., Ciftyildiz, K. ve Evkaya, C. (2019). Çoban çalışanların çalışma şartlarının iş hukuku açısından değerlendirilmesi: Atyolu Köyü örneği. Sosyal Siyaset Konferansları Dergisi, 76, 129-157. https://doi.org/10.26650/jspc.2019.76.0003 
long hours, irregular compensatory leaves, unregistered employment, and lack of social security constitute the most important problems for the shepherd. Moreover, it has been determined that there are many deficiencies in basic life requirements.

\section{Keywords}

Labour life • Shepherd's profession • Shepherd labour life • Atyolu, Şenkaya 


\section{Extended Summary}

The topic of research is those shepherds working using traditional methods. The original scope of the study was to cover shepherds and their families who earn their living through traditional methods in the villages of the districts of Oltu, Olur, Senkaya, Uzundere and Tortum in Erzurum province. However, due to the difficulty of reaching people, only the village of Atyolu village in the Senkaya district was chosen as the sample. The reason why this village was chosen as an example is because sheperheridng is practiced in this village as a profession. The area where the research was carried out is one of the villages that meets the needs of the shepherds. The aim of this study is to reveal the status of the shepherds working and earning income with traditional methods to determine their rights and interests in the modern period.

The method of our research is ethnographic and interpretive interactivity. Ethnographic research is the study of the material and spiritual cultures that emerge as a result of efforts to meet the economic and social needs of human communities in various times and places. In contrast, interpretive interaction is realized by interpreting the meaning of intension given by the person who performs the behavior. Data collection method was through participant observationin the research, which stand out as ethnographic and interpretive interactivity methods. The researcher continuously collected the data from both employer and employees. The observation period was between March 2017 and November 2018.

Shepherding is one of the rare professions that came from nomads time and exists till present days. It can be said that providing basic human needs such as food and clothing from animals is the biggest motivation for shepherding having existed as a profession for such a long time. From migratory to modern society, many changes have been experienced and this has affected the shepherding profession as well. The work of traditional shepherd, shaped according to agricultural society, continues in modern times as well. The job of the shepherd created the ways of a past the agricultural society does not adapt well to working conditions of the modern period because, working hours, forms of contracts, permits, responsibilities and rights of employees, which are prominent in terms of business law in the modern period, can be seen as an important factor in increasing the welfare of the shepherds. 
The research consists of three main parts. In the first chapter, the definition, rights and obligations of the shepherd were determined. The Turkish language institution defines the shepherding as the grazing herds of sheep and goats. But in the area where the research is done it is called the herd grazing people. The variety of the herd is not important and there is separate name for each herd. The name of the herd is given by the firtst name beginning of shepherd so it is known to whom the flock belongs to. The wage comes first among the rights of the shepherd. A small fraction of the fee is given in an advance and the remainder one is given at the end of the period. Provision of accomadation is another important shepherd's right. If the shepherd is not from the village, the village head and elders provide a place for them to stay in. As well as these two fundamental rights, there are also social benefits. Food and clothing are provided by many people, although they are not considered compulsory. The responsibility of the shepherd is grazing the animals. The main priority is to bring all the animals back to the barn in the evening . Other important obligations are the care of animals when they are ill searching for lost animals, notification of mating time, salt and water supply. In the second chapter, the status of the shepherd workers the village of was discussed.

A significant portion of the shepherd workers living in the village of Atyolu are working as shepherds in the villages outside for the reason that a small number of animals are in the village. Most of them go to agreed village in April, and when the term ends, they go back to their village. The working period is usually from May to November. This process is very much related to the earliest removal of the abdomen. In the third chapter, shepherds are evaluated in terms of labor law. In the study, it was revealed that the shepherds did not use their weekly leave, they made their contracts verbally, their working hours were twelve hours daily, the children of the shepherds did not receive sufficient education, they were not entitled to receive social security benefits and they worked on an informal basis. Morever, it is seen that the houses they live in are very small compared to other households, there is no bath and the toilets are outside the house. Fridge, oven, cooker, washing machine, dishwasher, television and iron which are considred as main necessities today are not genrally found in their homes. While television, refrigerator and tube cookers can be found at times other modern appliances simply arent available at all. 


\section{Çoban Çalışanların Çalışma Şartlarının İş Hukuku Açısından Değerlendirilmesi: Atyolu Köyü Örneği}

İnsanların temel gereksinimlerinden olan giyinme ve beslenme ihtiyacı ilkel insandan bugüne kadar çoğunlukla bitki ve hayvandan sağlanmaktadır. Hayvanların giyim ve beslenmede önemli olmaları hayvanlara günlük bakmakla yükümlü olan çobanların da önemini artırmaktadır.

İlkel insanın çobanlığı ile bugünkünün arasında çok önemli farklılıklar olduğu söylenebilir. Çobanlık açsından önemli olan hayvan sayısı, otlak bulma sorunu, et, süt, deri ve yününden yararlanma biçimleri ilkel insandan bugünküne kıyasla oldukça geliştiği görülebilir. Ancak o günden bu güne insanın hayvanla olan geçim ilişkileri devam etmektedir.

Bugünkü durumda çobanların birçoğu işverene bağlı olarak çalışmaktadırlar. Aynı zamanda geleneksel çobanlığın devam ettiği birçok yer de mevcuttur. Modern çobanlıkta yaz ve kış bakımları çalışan tarafından yapılırken geleneksel çobanlıkta kış bakımları hayvan sahipleri tarafından, yaz bakımlarının bir kısmı çobanlar tarafından yapılmaktadır. Bu çalışmanın kapsamını geleneksel çobanlığa devam eden ve geleneksel köy üretiminin devamını sağlayan kişiler oluşturmaktadır. Bu kişiler kısmen modern hayattan etkilenmelerine karşın üretim süreçlerinde çoğunlukla geleneksel geçim türü yaklaşımıyla hayatlarını devam ettirmektedirler.

İş hukuku, çalışanları yani emeğini satarak geçinenleri korumaya yönelik olarak gelişmiştir. 1900'lü yıllardan önce medeni hukuk içerisinde ele alınan iş ilişkileri sonraki süreçte borçlar hukuku içerisinde değerlendirilmeye başlanmıştır. Son dönemde iş hukukunun kendine has kanunları bulunmaktadır. Geleneksel dönemde iş ilişkileri genelde örf ve adete göre düzenlenmektedir.

Modern dönemde, modern hukuktaki iş hukuku yerine devam eden örf ve adetlerin, çoban çalışanların refah seviyelerinin yükselmesinde engel teşkil ettiği söylenebilir. Çünkü bu dönemde yaşayanların çoğu kendisini modern hukuk içerisinde değerlendirmekte ve iş ilişkilerini modern hukuka göre yürütmektedir. Örf ve adete göre çalışanlar modern hukukun sağlamış olduğu birçok hak ve çıkardan yararlanamamaktadır. Bu hak ve çıkarlardan yararlanabilmek için çobanlık mesleğinin modern döneme göre yapılandırılmasının kaçınılmaz olduğu söylenebilir. 
$\mathrm{Bu}$ çalışmada, iş hukukunun emeği korumaya yönelik getirmiş olduğu sözleşme, çalışma süresi, izinler, ücretler, primler ve teşkilatlanma konularının çoban çalışanlar için de uygulanmasının elzem olduğu üzerinde durulmaktadır.

\section{Yöntem}

$\mathrm{Bu}$ çalışma, Türkiye'de geleneksel çobanlık mesleğini ve sorunlarını inceleyen ilk makale olmasının yanı sıra gelenekten modern döneme geçişte çobanlık mesleğinin geleneksel biçimde devam etmesinin çoban çalışanların hayat standartlarının diğer çalışanlardan daha aşağıda kalmasını görmemiz bakımından önemlidir.

Çalışma yaşamı, insanlığın varlığı ile beraber var olagelmiştir. Göçebe dönemlerde insanların tabiata bağımlığı yüksekken, tarım döneminde bu kısmen azalmıştır. Bağımlılık tabiattan toprağa doğru küçülmüştür. Modern dönemde çalışanların bağımlılığı ücretler üzerinden düşünülebilir. Her bir aşama insanlığa önemli kolaylıklar sağlarken bir yandan da zorluklarını beraberinde getirmektedir. Modern dönemin en büyük handikapı işçilerin emeğini satıp geçinmenin dışındaki kazanç kapılarını aralama zorluğudur.

Modern dönemde işçi bakımından önemli sayılan ücret, emeklilik, iş kazası, meslek hastalığı, sosyal güvenlik, işsizlik vb. ödemeleri geleneksel çalışanlarda söz konusu değildir ya da çok azından bahsedilebilir. Yapılan araştırmada çoban çalışanların yukarıda sayılan haklardan sadece ücreti alabildikleri ortaya konulmuştur. Bu kişilerin modern dönemde geleneksel biçimde çalışmaları, yaşam standartlarının yükselebilmesinin önündeki en büyük engeli teşkil edebilmektedir.

Araştırmanın konusunu geleneksel yaşam biçimi içerisinde çalışma hayatını devam ettiren çoban çalışanlar oluşturmaktadır. Çobanlığın yükümlülükleri ve haklarının neler olduğu, hangi haklardan mahrum oldukları ortaya konulmaktadir.

Araştırmanın evrenini Erzurum ilinin Oltu, Şenkaya, Olur, Uzundere ve Tortum ilçelerinin köylerinde çalışan çobanlar oluşturmaktadır. Gerek iklim gerekse fiziki koşullar dolayısı ile tüm köylere ulaşmanın zor olmasından ötürü Şenkaya ilçesinin Atyolu köyü örneklem olarak seçilmiştir.

Bu köyde ikamet edenlerin çoğunluğunun çobanlık mesleğinde çalışması 
çobanlıkla ilgili bilgilerin elde edilebilmesinde önemli bir faktör teşkil etmektedir. Diğer yandan bu köyün araştırma bölgesi olarak seçilmesinde aşağıda belirtilen nedenler de önem arzetmektedir:

- Köyde çobanlık yapan ailelerin nüfusunun köyün genel nüfusa oranının yüksek olması

- Köyün bu civardaki köyler arasında çobanlık mesleği ile ünlü olması

- Köy nüfusunun göç oranlarının düşük seviyede olması

- Köyde yaşayanlar arasında genç oranlarının yüksek olması

- Çoban niteliği ile göç etmesi

- Tarım işlerinden uzak durmaları ve bunun karşılığında hayvancılığın önemli görülmesi

- Araştırmacının bu bölgeyi iyi tanıyor olmasından dolayı ile bilgiye ulaşılabilirliğinin güçlü olması

Araştırma; yorumlayıcı etkileşimcilik ve etnografyadan yararlanılarak hazırlanmıştır. Doğal ortamında gözlem yapılarak yorumlama yoluna gidilmiştir. Yorumlayıcı etkileşimcilik; sosyal bilimcinin, davranışı gerçekleştirenin verdiği anlam üzerinden anlam çıkarması ve yorumlaması ile gerçekleşmektedir.

Toplum içerisinde her bireyin farklı bir yapısı bulunmaktadır. Bireyin biyografisi sosyal bilimler açısından son derece önemlidir. Özellikle karar verme süreçlerinde her bireyin kararlarının değiștiren farklı etmenlerin olduğu ortaya konulmaktadır.

$\mathrm{Bu}$ yöntem, nesnellikten uzaklaşarak öznelliğe doğru kayması yönü ile eleştirilmektedir. $\mathrm{Bu}$ noktada araştırmacının bilgiyi devamlı ön planda tutarak, anlamlandırma ve yorumlamaları bilgi çerçevesinde yapması önem arz etmektedir.

Etnografya, terim olarak insan topluluklarının çeşitli zaman ve yerlerde ekonomik ve sosyal ihtiyaçlarını karşılamak için sarf ettikleri gayretlerin sonucunda ortaya çıkan maddi ve manevi kültürlerin tasvir analizlerini yapan bilim dalının adıdır. 
Araştırmanın verileri Nisan 2017-Kasım 2018 tarihleri arasında toplanmıştır. Bu süreçte temel etnografik veri toplama tekniği olan katılımcı gözlem kullanılmıştır. Gözlem ve alanla ilgili çeşitli kaynaklardan elde edilen bilgiler katılımcıların verdikleri anlamlar yoluyla mekanik olmayan bir tarzda yorumlanarak sosyal yapıya bağlanmıştır. 25 katılımcı ile söyleşi ve esnek akışta yapılan görüşmeler, alanla ilgili gözlem ve incelenen kaynaklar yoluyla edinilen kanaatler doğrultusunda yarı yapılandırılmış ve etkileşim içinde kendiliğinden ortaya çıkan yapılandırılmamış biçimde gerçekleşmiştir. Kişilerin arasına katılarak toplanan veriler genelde görüşme sonralarında kayda geçirilmiştir. Kişilere sürekli izleniyor olma hissi verilmesi araştırma süreci açısından zararlı görülmüş ve bundan kaçınılmıştır. Kişilerden, söylemleri ve gözlem sonucunda toplanan verileri araştırmacı yalnız kaldıkça ve firsat buldukça not defteri üzerinde kayıt altına almıştır. Kişilerin söylemleri ile gözlem sonucu ortaya çıkan davranışları farklılık gösterebilmektedir. $\mathrm{Bu}$ farklılıkları en aza indirmek, asıl olanı ortaya çıkarmak için söylem ve davranışlar arasındaki tutarlılıklar üzerinde de çok durulmuştur. Gözlem kayıtları bir bütünlük içinde araştırmaya aktarılmıştır.

Tablo 1

Katılımcıların özellikleri

\begin{tabular}{|c|c|c|c|c|c|c|c|}
\hline $\begin{array}{l}\text { Katılımcı } \\
\text { Numarası }\end{array}$ & Cinsiyeti & Yaşı & $\begin{array}{l}\text { Medeni } \\
\text { Hali }\end{array}$ & $\begin{array}{l}\text { Çocuk } \\
\text { Sayısı }\end{array}$ & Açılklama & \begin{tabular}{|l} 
Otlattığı \\
Hayvan \\
Sürüsü \\
Türü \\
\end{tabular} & $\begin{array}{l}\text { Hanesinde } \\
\text { Yaşayanlar }\end{array}$ \\
\hline G1 & Kadın & 41 & Evli & 4 & $\begin{array}{l}\text { Köy } \\
\text { dışında, } \\
\text { çobanın eşi }\end{array}$ & $\begin{array}{l}\text { İnek } \\
\text { Sürüsü } \\
\text { (Sağın) } \\
\end{array}$ & $\begin{array}{l}\text { Eşi ve } \\
\text { Çocukları }\end{array}$ \\
\hline G2 & Erkek & 40 & Evli & 4 & $\begin{array}{l}\text { Köy } \\
\text { dişında, } \\
\text { çoban }\end{array}$ & -- & $\begin{array}{l}\text { Eşi ve } \\
\text { Çocukları }\end{array}$ \\
\hline G3 & Kadın & 12 & Bekâr & Yok & \begin{tabular}{|l} 
Köy \\
dışında, \\
çobanın \\
kızı
\end{tabular} & -- & $\begin{array}{l}\text { Anne Babası } \\
\text { ve Kardeşleri }\end{array}$ \\
\hline G4 & Erkek & 13 & Bekâr & Yok & \begin{tabular}{|l} 
Köy \\
dışında, \\
çobanın \\
oğlu
\end{tabular} & -- & $\begin{array}{l}\text { Anne Babası } \\
\text { ve Kardeşleri }\end{array}$ \\
\hline G5 & Erkek & 27 & Evli & Yok & $\begin{array}{l}\text { Köy } \\
\text { dişında, } \\
\text { çoban }\end{array}$ & $\begin{array}{l}\text { İnek } \\
\text { Sürüsü } \\
\text { (Kısır) }\end{array}$ & Eşi ve Annesi \\
\hline G6 & Kadın & 25 & Evli & Yok & $\begin{array}{l}\text { Köy } \\
\text { dışında, } \\
\text { çobanın eşi }\end{array}$ & -- & $\begin{array}{l}\text { Eşi ve } \\
\text { Kaynanas1 }\end{array}$ \\
\hline
\end{tabular}




\begin{tabular}{|c|c|c|c|c|c|c|c|}
\hline G7 & Erkek & 32 & Evli & 3 & $\begin{array}{l}\text { Köy } \\
\text { dişında, } \\
\text { çoban }\end{array}$ & \begin{tabular}{|l} 
İnek \\
Sürüsü \\
(K1sır) \\
\end{tabular} & $\begin{array}{l}\text { Eşi ve } \\
\text { Çocukları }\end{array}$ \\
\hline G8 & Kadın & 30 & Evli & 3 & $\begin{array}{l}\text { Köy } \\
\text { dışında, } \\
\text { çobanın eşi }\end{array}$ & -- & $\begin{array}{l}\text { Eşi ve } \\
\text { Çocukları }\end{array}$ \\
\hline G9 & Erkek & 26 & Evli & 1 & $\begin{array}{l}\text { Köy } \\
\text { dişında, } \\
\text { çoban }\end{array}$ & $\begin{array}{l}\text { İnek } \\
\text { Sürüsü } \\
\text { (Sağın) }\end{array}$ & Eşi ve Çocuğu \\
\hline G10 & Kadın & 23 & Evli & 1 & $\begin{array}{l}\text { Köy } \\
\text { dışında, } \\
\text { çobanın eşi }\end{array}$ & -- & Eşi ve Çocuğu \\
\hline G11 & Erkek & 24 & Bekâr & Yok & $\begin{array}{l}\text { Köy } \\
\text { dişinda, } \\
\text { çoban }\end{array}$ & $\begin{array}{l}\text { İnek } \\
\text { Sürüsü } \\
\text { (Sağın) }\end{array}$ & Kardeşleri \\
\hline G12 & Erkek & 21 & Bekâr & Yok & $\begin{array}{l}\text { Köy } \\
\text { dişında, } \\
\text { çoban }\end{array}$ & $\begin{array}{l}\text { Büyükbaş } \\
\text { Yavru } \\
\text { Sürüsü } \\
\text { (Dana) }\end{array}$ & Kardeşleri \\
\hline G13 & Erkek & 20 & Bekâr & Yok & $\begin{array}{l}\text { Köy } \\
\text { dişında, } \\
\text { çoban }\end{array}$ & $\begin{array}{l}\text { Büyükbaş } \\
\text { Yavru } \\
\text { Sürüsü } \\
\text { (Dana) }\end{array}$ & Kardeşleri \\
\hline G14 & Erkek & 27 & Bekâr & Yok & $\begin{array}{l}\text { Köyde, } \\
\text { çoban }\end{array}$ & -- & Anne-Baba \\
\hline G15 & Erkek & 71 & Evli & 3 & $\begin{array}{l}\text { Köyde, } \\
\text { çalışmıyor }\end{array}$ & -- & Eşi \\
\hline G16 & Kadın & 65 & $\begin{array}{l}\text { Eşi } \\
\text { ölmüş }\end{array}$ & 4 & $\begin{array}{l}\text { Köy } \\
\text { dişında, } \\
\text { çobanın } \\
\text { annesi }\end{array}$ & -- & Çocukları \\
\hline G17 & Kadın & 45 & Evli & 5 & $\begin{array}{l}\text { Köyde, } \\
\text { kendi }\end{array}$ & -- & $\begin{array}{l}\text { Eşi ve } \\
\text { Çocukları }\end{array}$ \\
\hline G18 & Erkek & 50 & Evli & 5 & $\begin{array}{l}\text { Köyde, } \\
\text { kendi }\end{array}$ & -- & $\begin{array}{l}\text { Eşi ve } \\
\text { Çocukları }\end{array}$ \\
\hline G19 & Erkek & 62 & Evli & 4 & $\begin{array}{l}\text { Köyde, } \\
\text { çalışmıyor }\end{array}$ & -- & $\begin{array}{l}\text { Eşi ve } \\
\text { Çocukları }\end{array}$ \\
\hline G20 & Erkek & 65 & Evli & 6 & $\begin{array}{l}\text { Köyde, } \\
\text { çalışmiyor }\end{array}$ & -- & Eşi \\
\hline G21 & Erkek & 67 & Evli & 4 & $\begin{array}{l}\text { Köyde } \\
\text { çalışan }\end{array}$ & & Eşi \\
\hline $\mathrm{G} 22$ & Erkek & 63 & Evli & 3 & $\begin{array}{l}\text { Köyde } \\
\text { çalışan }\end{array}$ & -- & Eşi \\
\hline G23 & Kadın & 63 & Evli & 3 & $\begin{array}{l}\text { Köyde } \\
\text { çalışan }\end{array}$ & -- & Eşi \\
\hline $\mathrm{G} 24$ & Kadın & 61 & Evli & 4 & $\begin{array}{l}\text { Köyde } \\
\text { çalışan }\end{array}$ & -- & Eşi \\
\hline G25 & Erkek & 51 & Evli & 4 & $\begin{array}{l}\text { Köyde } \\
\text { çalışan }\end{array}$ & -- & \begin{tabular}{|l|} 
Eşi ve \\
Çocukları
\end{tabular} \\
\hline
\end{tabular}


Tabloda görüldügü üzere gözleme katılan 25 katılımcının büyük bir çoğunluğunu erkekler oluşturmakla birlikte bir gözlem grubuna dahil edildiği üzere köydeki bir kısım çobanlık faaliyetleri de bayanlar tarafından gerçekleştirilmektedir. Gözleme katılanların büyük bir kısmı evli iken küçük bir miktarı ise bekardır.

\section{Bulgular}

Araştırma üç ana bölümden oluşmaktadır. Birinci bölümde çobanın tanımı, hakları ve yükümlülükleri ortaya konulmuştur. İkinci bölümde, Atyolu Köyü çoban işçilerinin durumları ele alınmıştır. Üçüncü bölümde, çoban olarak çalışanların iş hukuku açsından değerlendirilmesi yapılmaktadır.

\section{Çoban Çalışanlar}

Türk Dil Kurumu çobanı, koyun ve keçi sürülerini otlatan kişi olarak tanımlamaktadır. Çoban kelimesine eş anlamlı olarak bazı yeni kaynaklarda sürü yöneticisi de denilmektedir. Eski Türkçede çoban terimi yerine sı ğırtmaç kullanılmaktadır. Küçükbaş hayvan güdücüsüne çoban denirken, sığır sözcügüne benzediği için büyükbaş hayvan güdücüsüne sığırtmaç denmiştir (İleri, 2011: 16). Hatta bazı Osmanlı metinlerinde çoban "davar eri" olarak bile adlandırılmaktadır (Ögel, 1985: 31). Çobanlık, yaydığ1 hayvana türüne göre, göçebe ve yerleşik hayvan otlatmasına göre, uzun dönemli ve mevsimlik olmasına göre, işverenine göre çeşitlere ayrılabilir. Bu yörede çoban küçük ve büyük baş hayvanları otlatan kişilere denmektedir. Körpe (kuzu), davar (keçi ve koyun sürüsü), nahır (inek sürüsü) dana, öküz, kısrak (kısır inek) sürüleri bulunmaktadır. Bu sürüleri otlatanlara çoban denilmektedir. Bu yörede çobanın çeşitleri sürüsüne göre değişmektedir (G2 ,G7, G9, G11, G19). Ancak çoban çeşitleri her yöreye göre farklılaşabilmektedir (Azizova, 2007:47).

Köy çalışmaları 1950'li yıllardan sonra, göçlerin artması ile önem kazanmaya başlamıştır. Bir yandan şehre göçler şehirde farklılıklar oluştururken diğer yandan da köyden çıkanların köyü etkilemeleri ile köy yaşamının değişmesine neden olmuşlardır. Ulaşım ve iletişim araçlarının gelişmesi ile yeni küresel yaşam biçimi kendini göstermeye başlamıştır. Türkiye'de köyle ilgili Kıray(1964), Geniş (2009), Berkes, Bora’nın çalışmaları ilk örnekleri teşkil etmektedir. 
Gerek sanayileşme ile ilgili olsun gerek sanayileşememe ile alakalı olsun köyler sürekli araştırılması gereken yerler olarak görülmüştür. Bazı köyler sanayileşirken bazılarının sanayileşememesi ya da işçileşememesi iki ayrı konu olarak karşımıza çıkmaktadır.

işgücü piyasaları birincil ve ikincil piyasalar olmak üzere iki grupta ele alınmaktadır. İkincil ikincil işgücü piyasasına, daha az ekonomik kontrole sahip, daha küçük ve kurumsallaşmamış firmalar hakimdir. Bu piyasadaki işler, düşük ücretli, part-time veya düzensiz çalışma saatlerinin olduğu ve kariyer imkanlarının olmadığ 1 veya az olduğu işlerdir. Düşük bir sendikalaşma oranı olduğundan çalışanlar işsizliğe karşı korunmasızdırlar (Çetinkaya, 2010:52). Çobanlık mesleği ikincil piyasa içinde yer almakta olup bu grubun içinde en az iş güvencesine sahip mesleklerden biridir.

Çobanlık, en fazla bilinen mesleklerden olmasına karşılık iş hukuku kapsamına girdiği söylenemez. Uzun süren araştırma sonucunda, Erzurum ve Ağrı yöresinde kayıtlı çalışan çobana rastlanmamıştır. Modern yaşamla birlikte çobanlık kadim geleneğin bir parçası olarak görülmüş ve modern yapıdaki işçi statüsüne geçirilmesi bir türlü gerçekleştirilememiştir. Türkiye'nin Batı Bölgeleri'nde kayıtlı işçi statüsünde çalışan çobanlar zaman zaman haberlere konu olmaktadır. Ancak bununla ilgili sağlıklı ve geniş bilgilere henüz ulaşılamamıştır.

Çobanlarla ilgili fazla eser bulunmamaktadır. Edebiyat ve tarih kitaplarında çobanlık hakkında bilgi verilmektedir. Bunlardan en önemlisi çobanlık hakkında edebi tez yazan Vedat Çoban'dır. Emine Gürsoy Naskali’nin editörlügünü yaptığı Çoban Kitabı isimli eserinde ise çobanlık terimleri, gelenekleri ve kültürü hakkında bilgilere ulaşılabilmektedir. Tarih kitaplarında çobanlık mesleği üzerinde duran en önemli isim ise Elnure Azizova'dır. Türkiye genelinde tam olarak kaç çobanın çalıştığı, sorunlarının neler olduğu, hangi bölgelerde yoğunlaştığına dair herhangi bir bilgi bulunmamaktadır. Ancak çobanların bakmakla yükümlü oldukları küçük ve büyük baş hayvanların sayısı ya da köy sayıları dikkate alınarak çobanların sayısı hakkında tahmin yürütülebilir.

Toplam nüfusu 2000'den aşağı olan yerleşim yerleri köy olarak adlnadırılmaktadır (Çağlar, 1990:20). Köylü ise bu tanıma uygun fiziki ve sosyal mekan içinde yaşayan ve ağırlıklı olarak tarım, hayvancılık, el sanatları gibi uğraşlarla varlıklarını sürdüren kişi ya da kişiler olarak tanımlanabilir 
(Arslan, 1992:12). İçişleri bakanlığı verilerine göre 2019 yılında 18.285 köy ve 386 belde bulunmaktadır (https://www.e-icisleri.gov.tr/Anasayfa/ MulkiIdariBolumleri.aspx, Erişim, 21,05,2019). Belediye Kanununun değişmesi ile büyükşehirlere bağlı köylere mahalle statüsü verilmiş ve köy sayıları neredeyse yarıya düşmüştür. Veriler 1şığında her köy için en az bir çoban çalışan düşünüldüğünde çobanların sayısı azımsanmayacak kadar çok olmaktadır. Bu sayı geleneksel yöntemlerle hayvan işleri yapanlar için geçerlidir. Modern usullere göre hayvan bakımı yapanlar ayrı olarak değerlendirilebilir. Bazı köylerde bir çoban bulunurken hayvancılığın yaygın olarak devam ettirildiği bazı köylerde 3 çobana rastlanmıştır. Diğer yandan hiç çobanı olmayan köyler de mevcuttur. Çoban çalışanlar literatürde mevsimsel çalışan işçilere benzetilebilir. Ancak mevsimsel çalışma modern üretim süreçlerinde daha çok görülmektedir. Kitlesel üretimlerin yapıldığ büyük tarım arazilerinde birçok işçi toplu şekilde çalışmaktadır ve belirli süreli iş sözleşmesi uygulanmaktadır. Takım halinde çalıştıklarından dolayı da takım lideri tarafından sözleşme imzalanmaktadır. Mevsimsel işgörenlerin sözleşmelerinin hepsi yazılı olmasa da önemli bir kısmının yazılı olduğundan bahsedilmektedir. Çalıştıkları dönem içerisinde sigorta primlerinin kısmen ödendiği de bilinmektedir.

2017 ve 2018 yıllarında, Erzurum'un Tortum, Uzundere, Oltu ilçelerinin köylerinde Afganlı göçmenlerden birçok kişinin çobanlık yaptığı bilgisine ulaşılmıştır.Afganlıgöçmenlerin tercihedilmenedenlerininbaşındabubölgelerde çobanlık yapabilecek nitelikli kişilerin bulunmamasından kaynaklanmaktadır. Diğer yandan çobanlık mesleğinin itibarı düşük ve çalışma hakları bakımından eksik olduğundan kimse çoban olarak çalışmamakta ve çobanlık yerine kent merkezinde apartman görevlisi mesleğini seçmektedirler. Köydekilerin tarım ve hayvancılıkla ilgili işlere olan isteksizliği sadece bu yöreye ait bir durum değildir. Diğer bölgeler için de geçerlidir (Arslan, 2003:22).

\section{Çobanın Hakları}

Çobanın haklarından en önemlisi ücrettir. Çalışmanın karşılığında dönemlik olarak ücretlerini almaktadırlar. Diğer yandan hayvan sahipleri tarafından yiyecek sağlanmakta ve lojman tahsisi yapılabilmektedir.

Ücret. Geleneksel yöntemlerle çalışan çobanlar, yazılı olarak sözleşme yapmamaktadır. Çoban sözlü olarak ne kadar ücretle çalışacağını ihtiyar 
heyetine bildirir. Buna karş1lık ihtiyar heyeti de çobana ne kadar ücret verileceğini bildirir. Eğer aradaki fark fazla değilse anlaşma yoluna gidilir. Muhtarın başkanlığındaki ihtiyar heyeti bir dönemliğine (bir dönem genelde altı aydır) belirlenen hayvan sürüsünü otlatmak üzere çobanla sözlü olarak anlaşır. Sözleşme her ne kadar sözlü olsa da sözleşme çeşidi bakımından belirli süreli iş sözleşmesine ve takım iş sözleşmesine benzemektedir. Çünkü çobanın çalışacağı zaman dilimi bellidir ve takım kılavuzu diğer aile üyeleri adına da sözleşmeyi yapmış olur. Aileye bir takım denilirse takımın kılavuzu da baba olmaktadır. Sözleşme genelde baba tarafından yapılmaktadır (G1, G2, G7, G9, G11, G16, G24).

Ücret türlerinden ise götürü ücrete benzemektedir. Genelde 6 aylık süre için anlaşma yapılır ve 6 ay için alacağ 1 ücret pazarlık konusudur. Ücretin bir kısmı avans olarak verilir. Bir kısmı anlaşılan süre tamamlanınca alır. Anlaşma süresi tamamlanmadan kar yağarsa ve hayvanların otlağa gitme ihtimali olmaz ise sezon erken kapanır. Ancak çalışma süresi erken tamamlansa dahi kalan günlerin ücretleri verilir (G1, G2, G8, G9, G13, G16, G21).

Yiyecek ve Lojman Yardımı. Geleneksel çobanlığa devam eden kişilere köylerde yemek verilir. Ancak bu yemek sürekli değildir. Gönüllü olarak hayır yapmak isteyenler çobana ve ailesine çeşitli yardımlarda bulunurlar. Bu yardımlar arasında en önemlisi yiyecek yardımıdır (G1, G6, G8, G10, G16, G17, G24).

Genelde her çobana lojman sağlanmaktadır. Lojman olarak verilecek evin sahibi göç etmiş ya da ölmüş kişi olabileceği gibi köylüler tarafından çoban için hususi yaptırılmış ta olabilir. Genelde köylerde hoca, öğretmen ve çoban için ayrı ayrı yerler bulunur. Her üç çalışan için hususi olarak lojman yaptırılmış köyler olabildiği gibi hiç birisinin hususi olmadığ köyler de mevcuttur (G2, G5, G7, G11, G15, G20, G23).

Yukarıda bahsedilen yiyecek ve lojman yardımı sosyal ücret gibidir. Asıl ücretten karşılanmaz. Ücret eki olarak değerlendirilebilir (G2, G5, G6, G10, G15, G20, G21).

Çobanın hataları için sözlü uyarılarda bulunulur. Tavsiyeler yapılır. Çalışma zamanında verdiği zayiatlar ücretinden kesilmez. Mesela: en büyük zayiat hayvanı kurt kapmasıdır. Bunun için her ne kadar sözlü sitem edilse de çobanın as1l ve ek ücretlerine dokunulmaz (G2, G7, G15, G19, G20, G21). 


\section{Çobanın Yükümlülükleri}

Çoban hayvanları otlatırken sadakatle ve özenle iş görmek durumundadır. Danasını, kuzusunu koruması, mevsimlere göre otlatma yerlerini ayarlaması, günlük su içmelerine dikkat etmesi ve belirli günlerde tuz verilmesi çobanının önemli görevlerindendir. Her ne kadar çobanlar görevlerini sorunsuz yerine getirse de köyde birçok kişinin hayvanını otlattığından hayvan sahiplerinin çoğu çobana farklı telkinlerde ve şikâyetlerde bulunabilmektedir.

Hayvanları Otlatma (Otarma/Yayma). Çobanın asıl işi hayvanın otlatmadır. Otlatmayı çocukluktan beri öğrenmektedir. Dedesinden, babasından, arkadaş ve akrabalarından sürekli bu işi öğrenirler. İyi otlatanlar sürekli övülürken kötü otlatanlara sürekli sitemli, imalı sözler söylenmektedir. Bu imaların en önemlisi "hayvanlara gazete okutturmaktır". Hayvanlara gazete okutturdun demek otlak olmadığından hayvanların başlarının otlamak için yeterli derecede eğik olmadığı etrafi seyrettiği anlaş1ır (G2, G5, G7, G19, G20, G24).

Otlak bulmak, otlağın verimli şekilde kullanılmasını sağlamak, otlak dönemleriniayarlamakköylüileçobanınönemli meşgalelerini oluşturmaktadır ve bu durum genelde geleneksel ay hesapları ile yapılmaktadır (G2, G5, G7, G19, G20).

Kuraklık, otlak alanlarının azalmasını beraberinde getirmektedir. Hayvanlar zayıf kalmaktadır. Zayıf kalmaları etlerinin, sütlerinin azalması anlamına geldiği gibi çiftleşme arzusunu azalması anlamına da gelmektedir. $\mathrm{Bu}$ da üç önemli zarardır. Bunlar; et, süt ve yeni doğacak danadır (G2, G5, G7, G9, G15).

Hayvanları Koruma ve Tanıma. Çobanlar hayvanları korumakla yükümlüdürler. Çobanlar sürülerini, yırtıcıların saldırısından, yıldırım çarpmasından, sel kaçırmasından ve hastalıktan korumakla görevlidir (Çoban, 2015:13). Kurt birçok yerde çobanların düşmanıdır. Özellikle birçok hayvanı bir seferde telef etmesi çobanları sıkı önlem almaya itmektedir. Bu yüzden çobanlar genelde yanlarında kurtlarla mücadele eden iyi cins köpek bulundururlar (G2, G5, G7, G9, G15, G16, G19, G20, G25).

Yağmur yağdığında çoban kenarı çekilip yağmurun geçmesini beklemez. Yağmur esnasında, çobanın, hayvanları, olabilecek tehlikelerden kurtarması gerekmektedir. $\mathrm{Bu}$ tehlikelerin başında sele kapılma ve 
yıldırım çarpmasıdır. Tecrübeli çobanlar bu esnada ne yapılacağını iyi bilmektedir. Yıldırımlar özellikle ağaçlara çarpmaktadır. Bu durumda çobanlar ağaca uzak yerlerde bulunurlar ve bulundukları yerin en alçak rakımlı yerlerine doğru giderler. Rakımın düşük olduğu yerler de genelde derelerdir. Derelerde de sellere dikkat etmeleri gerekir (G2, G5, G7, G9, G15, G16, G19, G20).

Hayvanlar bazı ot çeşitlerini fazla yediğinde hasta olmaktadır. Hangi otun fazla yenildiği zaman hasta edeceğini çoban bilmelidir. Otlatırken bunlara dikkat etmesi gerekir. Hastalık durumunda çok fazla müdahaleleri olmaz ancak durumu ağır ise kesmesi gerekir ya da sahibine bildirip sahibinin çare bulmasını sağlayabilir (G2, G19, G20).

Hayvanların kaybolması da sık rastlanan vakalardandır. Bazen günlerce hayvanlar, sahibi ve çoban tarafından aranır. Hayvanı bulmak için çoban birkaç gün aynı otlak alanına tekrar tekrar gider (G15, G18, G19, G20, G23).

Çoban, hayvanların üremesinin köylüler için ne kadar önemli olduğunu bilir. Bir hayvanın yavrusu ve sütü sahibinin en önemi gelir kaynağıdır. Bir sene yavrulamayan hayvan zarar sayılır. Çünkü kış bakımı yapılmış, yazın ise çobana para verilmiştir. Bunların karşılığı hayvanın doğurması ile karşılanabilir. Çobanın buradaki en önemli görevi hayvanın kızıştığını yani çiftleşme zamanını sahibine haber vermesidir ya da boğaya götürmesidir (G2, G5, G15, G16, G19, G20).

Çoban sürüyü eğitir ve kendine alıştırır. Sürünün davranışlarını yörenin ekim alanına göre belirler. Hangi yolları kullanacağını onlara öğretir. Bu eğitim bazen zor kullanarak yapılırken bazen de ekmek ve tuzla yapılır. Bazı yörelerde her koyun sürüsünün içerisinde çobanın 1slık ve sesine göre sürüyü eğreğe giderken veya merada otlarken yönlendiren bir koyun bulunmaktadır (Ak, 2012:206). Bu durum çobanın işini oldukça kolaylaştırmaktadır.

\section{Çobanın Yardımcıları}

Eşeği ve köpeği: çoban işlerini daha layığı ile yapabilmesi için hem eşeğini hem de köpeğini eğitmesi gerekmektedir. Eşeği genelde yorulduğunda binmek ve yükünü taşıtmak için kullanırken köpeğini de sürüleri yönlendirmek ve kurtların sürekli tehdidine karşı kullanmaktadır. 


\section{Atyolu Köyü Çoban İşçileri}

Atyolu Köyü çobanları ile ünlü bir köydür. Hayvancılık üzerine deneyimleri çok fazladır. Tarımla ilgileri oldukça azdır. Tahıl, sebze ve meyve yetiştirilmemektedir. Hayvanı olanlar kendi hayvanları ile ilgilenirken hayvanı az sayıda olan ya da hiç olmayanlar genelde başkalarına çobanlık yaparak geçimlerini sağlarlar.

Bu bölüm, köyün genel özellikleri, kendi köyünde hayvanla uğraşanlar ve çoban olarak başkasının hayvanını güdenler olmak üzere üç başlıktan oluşmaktadır.

\section{Araştırma Bölgesinin Genel Özellikleri}

Atyolu Köyü’nün Erzurum İli’ne uzaklığı 177 km, Şenkaya İlçesi’ne uzaklığ1 41 km'dir. Erzurum-Ardahan anayoluna uzaklığ (google.com/maps/). Rakımı 1900 m’dir. Köy'de su şebekesi bulunurken kanalizasyon sistemi bulunmamaktadır. İlkokul ve ortaokul öğretiminin yapıldığı okullar mevcuttur. Lise binası yaklaşık 23 km uzaklıktaki Akşar mahallesindedir.

Güneyde Kayalısu Köyü, Kuzeyde Eski Atyolu, Doğuda Çamlıalan Köyü, Batıda Gülveren ve Dokuzelma Köyü vardır. Köy, Eski Atyolu'nun alt kısmında ve iki dağ arasında vadi görünümündedir. Köye ulaşım genelde Akşar'dan dolmuşlarla sağlanmaktadır. Akşar mahallesinden 23 km'lik yolun $3 \mathrm{~km}$ 'i asfalt $20 \mathrm{~km}$ 'si ise stabilize yoldur (google.com/maps/).

İlkokulda 95 öğrenci, 11 öğretmen, 12 derslik, 1 kütüphane, 1 laboratuvar, 2 lojman bulunmaktadır. Ortaokulda ise 92 öğrenci, 6 öğretmen ile 4 derslikte eğitim-öğretim görülmektedir. Var olan 2 Lojman, 68 m genişliğinde, 2 oda 1 salondan müteşekkildir ve sobalıdır.

Atyolu köyünün nüfusu ise 2012 yılına kadar artarak devam etmiştir. Bu yıldan sonra sürekli azalma görülmektedir.

\begin{tabular}{lccc|cccc}
\multicolumn{3}{c|}{ Adrese Dayalı Nüfus Kayıt Sistemi } & \multicolumn{4}{c}{ Genel Nüfus Sayımları } \\
\hline Yıl & Erkek & Kadın & Toplam & Yıl & Erkek & Kadın & Toplam \\
2017 & - & - & 548 & 2000 & 296 & 288 & 584 \\
2016 & - & - & 568 & 1990 & 161 & 211 & 372 \\
2015 & - & - & 616 & 1985 & 103 & 177 & 280
\end{tabular}




\begin{tabular}{lccc|cccc}
2014 & - & - & 655 & 1980 & 91 & 144 & 235 \\
2013 & - & - & 713 & 1975 & 112 & 100 & 212 \\
2012 & 370 & 345 & 715 & 1970 & 85 & 88 & 173 \\
2011 & 361 & 346 & 707 & 1965 & 84 & 77 & 161 \\
2010 & 356 & 356 & 712 & & & & \\
2009 & 366 & 347 & 713 & & & & \\
2008 & 355 & 334 & 689 & & & & \\
2007 & 318 & 312 & 630 & & & & \\
\hline
\end{tabular}

Erzurum'un ilçelerinin çoğu köylerinde nüfus hızla azalırken Şenkaya ilçesinde birçok köyün nüfusları aynı oranda azalmamıştır. 2012 yılından sonra bu köylerin nüfuslarında azalma olduğu söylenebilir. Yine de bu köylerin doluluk oranları oldukça yüksektir.

Hane halkı sayısı genelde 5-6 arasındadır. Çocuk sayıları genelde 4-5 civarındadır. 2016 yılı verilerine göre 18 yaş altı 299 kişi iken 18 yaş ve üstü 269 kişidir. Her ne kadar göçlerden dolayı 18 yaş ve üstünün sayısı azalsa da yine de bu oran oldukça fazladır. Köyde yaşayan kişilerin yarısından çoğu 18 yaş altındadır. Geçlerin fazla olması bu köyü diğer köylerden ayırmaktadır. Çünkü nüfus verilerine göre Türkiye genelinde köyde oturanların sayısı sürekli azalmakta ve aynı zamanda gençlerin oranı da oldukça düşük seyretmektedir.

Bu köyde, gençlerin fazla olması ve göç etmemiş olmamaları iki ayrı nedene dayandırılabilir. Birincisi geç okullaşması, ikincisi ulaşım zorluğudur. Şenkaya ilçesi okur-yazarlık oranları bakımından Türkiye'de ilk sıralara girmesine rağmen bu köyde okulun geç açılması ulaşım zorluğundan kaynaklı olabilir. Ulaşım zorluğunun sebebi ise anayoldan uzak olması ve yol yapmak için gerekli araç gerecin bol olmamasından kaynaklandığı söylenebilir. Göç etme kararında, ulaşım imkânları önemli yere sahiptir. Ulaşım imkânlarının yüksek olduğu yerlerde kişilerin kentle bağları erken dönemde başlamaktadır. Kente uygun niteliklerin elde edilmesi ile kişiler kolayca kente göç edebilmektedir (G14, G15, G17, G19, G20).

Otlak alanlarının azlığı ve aynı zamanda yüksek rakımlı olması tarım yapmaya elverişliliğini ortadan kaldırmaktadır. Her ne kadar bir dönem tarım yapılmışsa da sonraki dönemlerde tarım uğraşı köylü tarafından kaldırılmış ve hayvancılığa devam edilmiştir. Bunda en önemi etkenin otlak azlığı olduğu söylenmektedir. Hayvanları olan aileler hayvanlarını kış döneminde 
beslemek için dişardan sürekli ot, saman ve yem almaktadırlar. Bu durum yaptıkları işten elde ettikleri geliri oldukça düşürmektedir. Dışardan ot almak ve aynı zamanda köye getirmek oldukça maliyetli olmaktadır. Geleneksel hayvancıllğın yapıldığı köylerin çoğunda kış için gerekli olan hayvan yemleri yazın tarlalardan ve otlaklardan getirilerek depolanmakta ve kışın bunlar kullanılmaktadır (G14, G15, G16, G17, G18, G19, G20).

Evlilikler genelde aynı yaş grubu içerisinde olmaktadır. 20'li yaşlarda evlilik gerçekleştirilmektedir. Kadınların evlilik yaşı erkeklere göre biraz daha erkendir. Evliliklerde genelde boşanma görülmemektedir (G1, G16, G8, G10).

Atyolu'nda, bahar döneminde, birçok kişi çobanlık yapmak için dışarıya göç etmektedir. Ailenin bütün bireyleri mevsimlik göçe katılmaktadır. Bu köyden genelde çevre köy ve çevre ilçelerin köylerine çoban olarak gidilmektedir. Bazı kişiler gittikleri köylerde uzun süreli yani 5-10 yıl çobanlık yaparken bazıları sadece bir dönem kalabilmektedirler (G2, G16, G17, G18, G19, G20). Çoban olarak göç edenler her ne kadar mevsimlik olarak çalışsa da mevsimlik işçilere çok benzememektedir.

Genel olarak mevsimlik gezici tarım işçiliğinin çalışma koşullarının oldukça kötü olduğu, bunun üzerine eklendiği bilinmektedir (Koruk, 2010:28). Çalışma saatleri, göç biçimleri, çocuk çalıştırma yaşları, işin zorluğu bakımından mevsimlik çalışanlara göre daha iyi şartlara sahip oldukları söylenebilir. Çünkü mevsimlik işçilerin çalışma şartları oldukça zordur (Lordoğlu ve Etiler 2014: 14-18; Özbekmezci ve Sahil, 2004:262).

Tasarrufa çok meyilli değillerdir. Yıllık olarak hayatlarını organize ederler, hatta yıllıktan daha kısa süreli olduğu da söylenebilir. Çünkü çobanlıktan kazandıkları erken dönemde tükendiği için şehirlere gidip odun doğrama işi yapmaktadırlar. Diğer yandan da bazıları toplayıcılık yapmaktadır. Geçimleri üç meslek üzerinedir: çobanlık, odun kırıcılığı ve toplayıcılık.

Kararlar genelde aile reisi tarafindan alınmaktadır. Ancak bazı önemli konularda köyün ileri gelenlerinden görüş aldıkları da olmaktadır.

Boş zamanlarında oturup konuşmak yaşlıların en önemli uğraşıdır. Çocuklar ise kendi aralarında oyun oynayarak, televizyon izleyerek ve ders çalışarak zaman geçirirler. Kış aylarında okula önem verilirken yaz aylarında hayvanlarla uğraşırlar. 
Yemeklerinde en çok et kullanılır. Süt mamulleri de et kadar önemli yer tutmaktadır. Yemeklerinin genelde yerde yerler. Bazı yemekler ortaya konulup ortadan yenilirken bazıları ayrı ayrı servis edilmektedir.

Yaşam yerleri bir oda bir sofadan oluşmaktadır. Evlerin bazıları tek katlı bazıları çift katlıdır. Soba yakarak ısınırlar. Yüksek olduğu için neredeyse yılın tüm günlerinde soba yanmaktadır.

Evlerin çatısının sacla örtülü olması bu yörede çok rastlanan durumdur. Toprak çatının akıtması ve bakımının zor olması bu yönde değişime zorlamaktadır. Modern dönemde, köylerde ilk değişen evlerin çatılarıdır.

Köyün ormanlık alan içerisinde olması ve aynı zamanda odunun taşa göre daha hafif olması ev, ahır vb. yapılarda odunun sıkça kullanılmasının sebebidir. Diğer yandan köyde inşa edilen okul ve lojmanlar köyün ev inşasında kısmen etkili olduğu söylenebilir.

Bazı yörelerde otların konulduğu merekler yapılırken bazı yörelerde otlar dışarda yığın yapılarak muhafaza edilir. Odunun olmadığı yerlerde tezek önemli bir yakıttır ancak bu yörede odun bol olduğu için tezek çok az kullanılmaktadır. Hayvan gübreleri ahırların önlerine yığılmakta sonrasında ise bitkilerin dibine dağıtılmaktadır.

\section{Göçe Katılmayan Çoban İşçiler}

Bu kişiler köyde kendi hayvanlarını güden ya da kendi köylerinde çobanlık yapanlardan oluşmaktadır. Bu kişiler köy dışına çıkmamaktadır. Kendi köylerinde hayvan güderek geçimlerini sağlamaktadırlar. Köyde az hayvanı bulunan aileler, kendi hayvanlarını sıra ile güderler veya çoban tutarak hayvanların otlamasını sağlayabilirler. Bazı kişiler de başkalarının hayvanını kendi köyünde güderek gelir elde etmektedir. Bu kişiler köyün yakınında bulunan yaylada dönemin çoğunu geçirmektedir (G2, G5, G7, G9, G11, G12, G20, G23).

Otlatma dönemi genelde nisan ayının sonunda başlamaktadır. Haziran ayında yaylaya gidilmektedir. Yayladan eylül ayında dönülmektedir. Eylül ayı ile kasım ayı arasında geceleri köyde kalarak hayvanlar otlatılmaktadır. Yaylada belirli bir bölge çevrilerek hayvanlar için yer yapılmakta kendileri ise baraka biçiminde yayla evlerinde kalmaktadırlar. Su ihtiyaçları taşıma suyla 
sağlanmaktadır. Gündüzleri hayvanları otlatıp akşam ve sabahları hayvanların sütü sağılmaktadır. Bu sütten genelde peynir ve tereyağı yapılmaktadır. Tereyağı ve peynir kendi ihtiyaçlarını karşılaması esastır ve fazlasını satmaktadırlar (G2, G5, G7, G9, G11, G17, G18, G19, G12, G20).

\section{Göçmen Çoban İşçiler}

Göçmen çobanlar kışın kendi köylerinde yaşamlarını sürdürürken yaz aylarında anlaşabildikleri köylere gidip çobanlık mesleğini icra etmektedirler.

Çobanların Kış Aylarında Yaşamları. Yazın çoban olarak başka köyde yaşayanlar kış aylarında kendi köylerinde dönmektedirler. Bu durum, bu yörede gurbet göçüne kısmen benzemektedir. Ancak gurbet göçünde göç eden kişi yalnız göç etmektedir. Ailenin büyük çoğunluğu geride kalmaktadır. Bu göç türünde ise ailenin büyük çoğunluğu göç etmektedir. Genelde yaşlılar sürekli köyde kalmakta diğerleri mevsimsel olarak göç etmektedirler.

Kış aylarında çocuklar okula gitmektedir. Yazın kazandıkları gelirlerini kış aylarında tüketmektedirler. Gelirleri tükenince odun kırmak için kent merkezlerine gitmektedirler. Bazıları ise gelirleri tükenince, toplayıcılık yaparak yaşamlarını devam ettirmektedir. Kış aylarında gerek toplayıcılık yaparken gerek odun kırmaya giderken aileden bir ya da iki kişi gitmektedir. Yazın olduğu gibi ailece göç etmezler (G1, G6, G8, G9, G11, G12, G16).

Çobanların Yaz Aylarında Yaşamlart. Ailenin çoğu üyesi yani anne-baba ve çocuklar bu göçlere katılmaktadır. Ailenin büyük üyeleri kendi yerlerinde kalmaktadır. Aile gittiği yerde hem geçimlerini sağlamakta hem de kışın geçimlerinin sağlanması için sermaye biriktirmektedir.

Genelde ağ ilişkisi kullanılarak çobanlarla çoban arayanlar bir araya gelirler. Çobanlar dönemlik olarak kaç lira istediklerini köy muhtarına ya da köy ihtiyar heyetine bildirir. Çoban arayan kişiler de kendi düşündükleri ücreti söylerler. Götürü olarak genelde altı ay süreceği tahmin edilen süre için anlaşırlar. $\mathrm{Bu}$ süre genelde mayıs ayında başlayıp kasımda sonlanır. Ancak bu süre kesin değildir. Başlaması ve bitişi çeşitlilik gösterebilir. Eğer erken kar yağarsa bu süre çok kısa da olabilir. Ancak anlaştıkları ücrette kısıntı yapılmaz. Dönemlik ücret köydeki hayvan sayısına bölünerek hayvan sahiplerinden toplanır (G1, G2, G6, G7, G9, G11, G12, G20). 
Anlaşma sağlandıktan sonra çoban eşyalarını toplar, araba kiralar ve eşyasını çoban olarak çalışacağı köye getirir. Bu eşyalar temel eşyalardır. Yatak, yemek kapları, giyecek vb. dir. Birçoğunda bugün herkeste bulunduğu söylenen beyaz eşya tam değildir. Tüp ocağı hepsinde bulunsa da buzdolabı, firın, çamaşır makinesi, bulaşık makinesi ve televizyon birçoğunda yoktur. Tüp ocă̆1 ve buzdolabı dışında beyaz eşyaya rastlanmamıştır (G1, G6, G9, G16, G19).

\section{Çoban Çalışanların Çalışma Yaşamlarının İş Hukuku Bakımından Tahlili}

Her ne kadar geleneksel yöntemlerle çalışma hayatlarına devam etseler de birçok köyde geleneksel yöntemle yaşamını devam ettirenlerin sayısı oldukça düşük görülmektedir. Geleneksel tarımsal üretimin en önemli aracı öküz, neredeyse yok denecek kadar azdır. Öküzün yerini traktörler çoktan almış durumdadır. Traktörlerin tarımda bu kadar yoğunlukta kullanılması üretim süreçlerinin gelenekselden moderne doğru evirildiğinin önemli bir kanıtıdır. Tarım 4.0'ı konuşmaya başladığımız bugünlerde eski tip üretimden modern yapıya geçişin daha da hızlanacağı rahatlıkla öngörülebilmektedir.

Köydeki üretim süreçlerinin gelenekselden modern yapıya evirilmesi çoban çalışanları da direkt etkilemektedir. Çoban çalışanların da modern çalışma usul ve esaslarına göre haklarını elde etmeleri oldukça önemli görünmektedir. Çoban çalışanların çalışma yaşamlarının modern dönemin iş hukukuna göre düzenlenmesi gerekliliğine 1 şı tutması açısından bu araştırmanın önemli olduğu söylenebilir. Her ne kadar çobanlık mesleği mevzuat içerisinde çok anılmasa da Ulasal Meslek Standartları'nda meslek standartlarının yayınlanmış olması önemlidir.

\section{İş Sözleşmesi}

Çoban işçilerin çoğu iş sözleşmesini sözlü olarak yapmaktadır. Genelde dönemlik olarak anlaşmakta ve dönemin sonunda kendi memleketine geri dönmektedir. Her ne kadar çoban işçilerin sözleşmeleri sözlü olarak yapılsa da yazılı sözleşme yapmış kadar etkilidir. Genelde verilen sözler tutulur. Verilen sözlerin tutulmaması ile ilgili bir şikâyet duyulmamıştır. Yapılan şikâyetler genelde teferruatı ile ilgilidir. Dönemin ortasında inek almak ve çobanın sürüsüne katmak gibi meselelerde anlaşmazlıklar çıkabilmektedir. Ama bunlar genel sözleşmeye uyulmadığı anlamı çıkarılmaz. (G2, G5, G7, G13, 
G19). Her ne kadar Borçlar Kanuna göre iş sözleşmeleri aksine bir hüküm olmadıkça özel bir şekle tabi olmasa da, uygulamada ispat kolaylığı açısından yazılı olarak yapılması yaygın olan yaklaşımdır. Keza İş Kanunu'na göre de sadece 1 yıl ve üzeri süresi belirli sözleşmelerin yazılı olması şartı vardır. Şakar (2018)' e göre bu şekil geçerlilik şekli değil sadece ispat şeklidir. Oysa çobanlık mesleğini icra eden kişiler ile mal sahibi arasında yazılı sözleşme uygulamasına hiç rastlanmamıştır. Çıkacak olası anlaşmazlıklarda yazılı bir sözleşmenin var olmaması önemli ispat sorunlarına yol açabilmektedir.

Çobanını hizmetinden memnun kalınırsa ertesi yıl tekrar çoban olarak o yerde devam eder. Eğer köylü memnun kalmaz ise başka birisini ararlar. Köylüler için hayvanın iyi otlatılması yanı sıra çobanın kişiliği, kimliği, etnik kökeni, dini ve mezhebi ön plandadır. Dini inançlardaki farklılıklar köylünün çoban tercihinde öne çıkmaktadır. Köylünün kültür ve dinine yakın çoban bulunamaz ise o zaman farklı kültür, din ve mezhepten bir çoban ile anlaşırlar (G2, G5, G7, G19). İş Kanunu'na tabi olması durumunda işverenin keyfi sözleşme feshini önleyen ve feshin geçerli bir sebebe dayandırılması şartları dolayısı ile iş güvencesi hükümleri devreye girebilecek ve bu iş ilişkisinde zayıf taraf olan çobanlar iş güvencesine sahip olabileceklerdi. Çobanlık mesleğini icra edenler, haksız fesih söz konusu olması durumunda İş Kanunu 21. maddede zikredilen hususlar çerçevesinde mal sahibi işverenin ödemek durumunda olacağı bir takım tazminatlardan yoksun kalmaktadırlar.

\section{Çalışma, Dinlenme ve İzin Süreleri}

Çalışma süreleri güneşin doğmasını takiben 1-2 saat içerisinde başlar ve güneşin batışından yaklaşık 1-2 saat önce günlük çalışma son bulur. Erzurum yöresinde çoban işçiler sabah 6 ile akşam 6 arasında çalışmış olur. Hayvanların kaybolması veya bir yerde hastalanıp gelememesi neticesinde fazladan hayvan arama ve getirmeden dolayı olağan olmayan çalışmaları ara sıra olabilmektedir. Hayvanların öğlende otlamaya ara vermesi ile çobanlar da kısmen dinlenirler ki bu da resmi bir dinlenme süresi değildir. İş hukukunda geçerli olan haftalık 45 saat çalışma süresi (4857 Sayılı İş Kanunu, Madde: 63) dört gün içerisinde doldurulmaktadır. İş kanununda zorunlu olan (Madde 46) haftada bir gün izinlerini kullanamamaktadırlar. Ara dinlenmesi, hafta tatili, yıllık izin bulunmazken gece dinlenmesi söz konusudur. Gece en azından 11 saat kendilerine vakitleri bulunmaktadır (G2, G5, G7, G11). Oysa İş 
Kanunu Md. 68/1'de 7,5 saatten fazla süren işlerde en az 1 saat kesintisiz ara öngörülmüş̧ür. Çobanların bu aradan resmi olarak yararlandıklarını söylemek mümkün değildir. Yıllık izne çıkmaksızın yeni sürüyü devralmaları dolayısı ile uygun bir dinlenme dönemi de sahip değildirler. Bu durum hem vücut yorgunluğu nedeniyle hastalıklara ve iş kazalarına davetiye çıkarmaktadır.

Yaylada kalan çobanlar gece aynı zamandan sürülere bekçilikte yapmaktadırlar. Hem gece çalışmaları hem de gündüz çalışmaları onları oldukça yormaktadır. Bu süreçte en önemli yardımcıları köpekleridir. Özellikle çobanın gece uyuyabilmesini sağlamaktadır (G5, G7, G9, G12, G13, G18). Fazla Çalışma Yönetmeliği md.8/a kapsamında 18 yaşın altındaki çalışanların fazla mesai yaptırılmaması gerekirken çobanlık mesleğinde böyle bir sınırlama dikkate alınmamakta ve 18 yaş altında çok sayıda çoban bu şekilde çalışmaktadır. Yine çobanların bir kısmı bayanlardan oluşmakta ve Kadın İşçilerin Gece Postalarında Çalıştırılma Koşulları Hakkındaki Yönetmelik te her ne sebeple olsun bayanların gece döneminde fazla çalışma yapamayacağı ifade edilse de çobanlık mesleğini yürüten bayanların zaman zaman gece döneminde de çalışmak durumunda kaldıkları gözlenmiştir.

\section{Ücretleri}

Ücretlerini genelde dönemlik olarak almaktadırlar. Yaklaşık olarak altı aylık dönemi kapsayan çalışma sürelerinde bu dönem için 15-20 bin arasında ücret almaktadırlar. Ücretlerinin bir kısmın avans olarak peşin, çoğunu ise dönem sonunda alırlar. 15-20 bin lira alan birisi dörtte birini işe başlarken alır. Aralarda lazım oldukça dörtte birini daha alır. En sonunda da geriye kalan alacaklarını alarak dönemi kapatır. Ancak bu durum her çobana göre değişmektedir. Aile olarak gelip değişik sürülere ailenin üyeleri çobanlık yaparsa ailenin dönemlik kazancı oldukça fazla olabilir (G1, G2, G5, G7, G9, G12, G13, G18, G22). Oysa İş Kanunu kapsamında olan çalışanların ücretleri md.32 dahilinde en geç ayda bir Türk Lirası ile banka üzerinden ödenmesi gerekir ki çobanların ücret alacaklarının büyük bir bölümünü ancak 6 aylık periyodun bitiminde alabilmektedirler. Hatta zaman zaman ücretin bir bölümüne karşıllı hayvan verilmesi yolu ile ödeme yapıldığı da uygulamada karşımıza çıkmaktadır. Hem maaşı düzenli alamamak hem de zaman zaman para yerine ayni bir takım ödemelerin sunuluyor olması çobanlık mesleğini icra edenlerin düzenli bir yaşam standardı sürmeleri önünde bir engel teşkil etmktedir. 


\section{İş Sağlığı ve Güvenliği}

İş sağlı̆̆1 ve güvenliği olmasa da işin niteliği gereği meslek hastalığı ve iş kazasına çok az rastlanmaktadır. Ailenin bütün üyeleri çalıştıkları için kendileri birbirlerini ikame edebilmektedirler. Çok nadir de olsa bazen geçici hastalıklar olabilmektedir. Sürekli tabiatta olmaları, temiz hava almaları ve yürümeleri onların sağlıklı olmalarını sağladığ 1 söylenebilir. Ancak bazen yağmur altında kalıp üşüttükleri de olmaktadır. Özellikle çocuklar bu tür soğuk algınlıklarına maruz kalabilmektedir. Zaman zaman hayvanların yüksek yerlerde ve uçurum kenarlarında otlatılmaları sözkonusu olabilmektedir ki bu durum iş güvenliği ile alakalı ölümcül riskleri de beraberinde getirmektedir. Bunun dışında hayvanlardan insanlara bulaşabilecek hastalık risklerine karşı bir takım önlemlerin alınması hususunda alınmış bir önlemde mevcut değildir. Özellikle büyük baş hayvanlar ağırlıkları ve güçlerine paralel olarak yaralanmalı, işgünü kayıplı ve hatta ölümcül bir takım kazalara sebebiyet verebilmektedir.

Ulusal Meslek Standartı seviye 3'te çobanlık mesleği için iş sağlığı ve güvenliği ile ilgili olarak çobana "Çalışılan arazilerde ve ağıl/ahırda İSG ve acil durum önlemleri almak, Kişisel koruyucu donanım (KKD) kullanmak, Çevre koruma önlemleri almak, Mera kullanımında çevre koruma ve verimlilik sağlamak ve Yaptığı çalışmaların kalitesini denetlemek" şeklinde görevler yüklenmiştir (https://portal.myk.gov.tr/index.php?...3\%20Rev\%20 00\%20Çoban...PDF, erişim 24.05.2019; 22:50).

\section{Sağlık ve Sigorta Primleri}

Çalışmanın yapıldığı söz konusu yerde sigortalı çalışan hiçbir çobana rastlanmamıştır. Sağlık sorunu yaşadıklarında genelde yeşil kart kullanarak sağlık hizmetlerinden yararlanırlar. Emeklilikleri de bulunmamaktadır. Bakım desteklerinden de çok nadir yararlanmamaktadırlar. Bu durum hem çobanların kendileri hem de aileleri açısından bir takım sağlık ve gelecek problemleri oluşturabilmektedir. Oysa Gerek iş hukuku, gerek borçlar ya da diğer kanun hükümlerine göre çalışsın tüm çalışanların sosyal güvenceye dahil olma hakları var iken çobanlık mesleğini icra edenler bu güvenceden mahrum kalmaktadırlar. Kaldıki sigorta yapılmak istense dahi birçoğu aynı köyde birden fazla kişinin hayvanını yetiştirdiğinden primi hangi işverenin ne ölçüde ödeyeceğinin tespit ve tayini de uygulamada pek kolay görünmemektedir. 


\section{Teşkilatlanmaları}

Çoban çalışanlar arasında sendikalaşma söz konusu değildir. Hepsi bireysel olarak davranmaktadır. Diğer tüzel kişiliklerden hiç birisine de rastlanmamıştır. Sadece bulundukları köyün tüzel kişiliği bulunmaktadır. Çalışma sınırları, gelenek ve bireysel niteliklere göre şekillenmektedir. Gelenek, genel hukuki alanı çizerken bu hukuk içerisinde ücret, ayni yardım (ücretin yanı sıra verilen ek yardımlar), ayni ücret (ücretinin bir kısmının ürünlerle verilmesi; buğday, arpa, mısır, patates vb.) köy halkına ve çobana göre şekillenmektedir. Sendikalaşma durumları söz konusu olmadığı için işverene karşı ortak standart bir hak elde edebilmeleri de mümkün olmamaktadır.

\section{Sonuç}

Atyolu Köyü bugüne kadar kendi geleneksel yapısını devam ettirmiştir. Üretim süreçlerinde geleneksel yaklaşım ön plandadır. Kişiler, geçimlerini sahip oldukları hayvanlardan ve başka köylerde mevsimsel çobanlık yaparak sağlamaktadır.

$\mathrm{Bu}$ kişilerin diğer bir önemli geçim kaynağı ise odun kırıcılığıdır. Kış aylarında soba kullananlara odun kırarak gelir elde etmektedirler. Genelde ilçe merkezlerine gidip günübirlik ya da birkaç gün kalarak apartmanlar için odun kırmaktadırlar ki bu durum da gittikçe azalma eğilimindedir. Çünkü soba sisteminden kalorifer sistemine geçilmiş ve bundan dolayı odun kullanımı oldukça azaltmıştır. Bu durum çobanlık yapmadıkları dönemde gelir elde edilmelerini güçleştirmekte ve onları yeni bir takım iş alanı arayışlarına itmektedir.

Araştırmaya konu olan çobanlar;

-İş sözleşmelerini genelde sözlü olarak yapmaktadırlar. Çobanların kendi içlerinde il ya da ilçe bazında dernek tarzında bir dayanışmaya gitmeleri durumunda karşılıklı beklenti ve yükümlükler standart yazılı bir metine dönüşebilecek ve çobanlar olası anlaşmazlıklarda haklarını daha net savunabileceklerdir.

-Günlük çalışma saatleri 10-15 saat arasında değişmektedir. Bu süreler insani olmayıp olağanüstü bir çaba gerektirmektedir. Aynı zamanda hastalık ve iş kazalarına zemin oluşturduğundan bu çalışma saatlerine uygun nitelikte belirli dinlenme zamanları sağlayacak bir sistem oluşturulmalıdır. 
-Haftalık izinleri bulunmamaktadır. Haftada en az bir gün dinlenmelerini sağlayacak bir sisteme gidilmelidir. Genelde altı ay çalıştıkları için yıllık izin söz konusu olmamaktadır. Hem dinlenme süresi hem de izinler için ilçe bazında bir joker eleman niteliğinde bir çoban istihdam edilip bunun o ilçeye bağlı tüm köylere hizmet vererek belli zaman aralıklarında diğer çobanların istirahat etmeleri şeklinde bir çözüm geliştirilebilir.

-Sosyal güvenlik kayıtları bulunmamaktadır. Çobanların toplu hareket etmeleri durumunda en azından tarım bağkuru primlerinin belli bir bölümü ya da tamamının mal sahibi işverence karşılanması çobanlar açısından bir çözüm yolu olabilecektir ki bu durum hem çobanlarım hem de ailelerinin gelecekleri açısında kendilerini güvende hissetmelerini sağlayacaktır.

-Aile 6 aylık zaman sürecinde 15-20 bin TL arasında ücret almaktadır. Bazı durumlarda ailenin diğer üyeleri başka hayvan sürüleri otlatırsa gelirleri artmaktadır. Aylık bazda asgari ücretin üstünde gibi görünse de sosyal güvenlik primlerinin ödenmiyor olması dolayısı ile yaşadıkları kayıp düşünüldüğünde tek başına yeterli bir ücret değildir. Ödeme zamanları da iş bitimi yerine düzenli periyotlar ile ödeme şeklinde dönülmesi çobanların ve ailelerinin yaşamlarını daha iyi planlayabilmelerine katkı sağlayacaktır.

-Ailenin genelde bütün bireyleri çalışmaktadır. Çocuk yaştakilerin çalışması sözkonusu olmakla birlikte, çocukların çok aşırı çalıştırıldığı da söylenemez. Bununla birlikte henüz okul çağındaki çocuklar dahi okula gitmek yerine erken yaşta çobanlığa başlayabilmektir ki Koruk (2010)'un çalışmasında da bu çalışmadaki verilere paralel olarak geçici mevsimlik tarım işi yapan ailelerdeki ergenlerin \%39,4'ü ilkokul altı eğitim düzeyinde olduğu görülmektedir. Erken yaşta çobanlığa başlıyor olmak eğitim seviyesinin düşmesine sebebiyet vermektedir. Okula devam eden çocukların eğitimleri ile ilgili de sorunlar bulunmaktadır. Çünkü okul dönemi 9 ay, buna karşılık çalışma dönemi 6 aydır. Yaklaşık 2-3 ay daha az okula gidebilmektedirler.

On beş yaşından küçüklerin iş kanuna göre çalıştırılmaları yasakken 8-14 yaşında çalışan birçok kişi bulunmaktadır. Ancak çocuk yaşta çalışanlar zor işlerde çalışmazlar. Genelde anne babasına çobanlık sırasında yardım etmektedirler.

Eğitim, günümüzde sosyo-ekonomik gelişmenin temel araçlarından birisi olarak kabul edilmektedir(Fidan, 2010, 146). Çobanlık yapanların çocuklarının 
eğitimi de yarım kalmakta ve bu gelişim mümkün olamamaktadır. En azından bu kişiler için 6 aylık süre dikkate alınarak yoğunlaştırılmış dersler verilebilir.

-Yaşam şartları oldukça zordur. Temel yaşam gereksinimlerini zor karşılamaktadırlar. Birçoğunun evinde buzdolabı, çamaşır makinesi, firın, bulaşık makinesi bulunmamaktadır. Hem ücret seviyesinin düşük olması hem de kırsal alanda yaşama zorunluluğu bu durumun temel sebepleri olarak karşımıza çıkmaktadır.

-Erzurum'un köylerinde merkeze çok yakın olanlar dışında topraksızlaşma görülmemektedir. Göç edenlerin köylerde toprakları durmaktadır. Bazıları istediği takdirde köylerine dönüp tarım işleri yapmakta ve yeni evler inşa etmektedirler. Ancak Atyolu Köyü'nde yaşayanlarda toprak sahibi olması söz konusu değildir. Yalnızca evleri için belirli bir arsaya sahiptirler ve belirli miktarda otlakları bulunmaktadır. Tarla ve bağ-bahçe bulunmamaktadır.

-Küçükbaş hayvancılığın azalmasında en büyük etken çoban yokluğudur. Çoban olmadığı zaman kişiler sıra ile hayvanları yaymak için gitmektedir. $\mathrm{Bu}$ durum, köylülerin diğer işlerinin aksamasına sebebiyet vermektedir. Diğer yandan ailedeki genç işçiler göç ettiği için kişi başı iş oranı oldukça artmış durumdadır. Çobanlık dişında iş yapanlar günlük 10-16 saat arası çalışmaktadırlar.

-Çoban olarak gittikleri köylerde gerek mezhep farklılıkları gerek kültür farklılıkları, gerekse de siyasi görüş farklılıkları onların sürekli çoban olmalarına ya da çobanlıktan ayrılıp başka iş yapmalarının önünde engel teşkil ettiği söylenebilir. Kendilerini toplumun genelinden soyutlanmış olarak görmektedirler. Bunun birkaç önemli nedeni olabilir. Çobanlık mesleğinin saygınlığının az olması, farklı mezhep ve siyasi görüşün getirmiş olduğu farklı kültür kalıpları onları diğer toplumlardan ayırmaktadır.

Köyün arazisinin az nüfusunun çok olması nedeni ile sürekli komşu köylerle arazi kavgası olmaktadır. Her ne kadar sayılarının fazlalığı ile diğer köylere üstünlük sağlasalar da otlak bulma kaygısı süreklilik arz etmektedir.

Köyden göç etme eğilimleri fazladır ancak şimdilik göç için firsat bulma zorlukları bulunmaktadır. Şehirde niteliklerine göre iş bulmanın önceki yıllara göre zorlaşması, göç edecek network ağının bu köyde yetersiz oluşu, köyde geleneksel olarak alışmış oldukları ortak yaşam ve ekonomik değerlerin 
şehirde olmaması göç etme isteklerine ket vurmaktadır. Kollektif yaşama yatkınlıkları şehirlerde var olan bireysel yaşamla örtüşmemektedir. Yukarda sıralanan bu farklılıklar onların köyden göç etmelerine engel olmaktadır. Bu bölge için hayvancılığın çeşitli teşvikler ile daha cazip hale getirilmesi hem göç fikrini tamamen ortadan kaldırıp hem de daha fazla kazanç imkanı ile çobanlık mesleğinin gelişimine katkıda bulanabilecektir.

Araştırmanın yapıldığı köylerde gençler kente göç etmektedir. Köylerde yaşlılar yalnız kalmaktadır. Yaşlıların az sayıda da olsa büyükbaş hayvanları bulunmaktadır. Yaşlıların eşleri öldüğü zaman hayvanlarını satıp ya çocuklarının yanına kente gitmektedir ya da tek başına köyde herhangi bir uğraşı olmadan zamanını geçirmektedir. Bu durum için şu öneri yapılabilir. TOKİ tarafından modern ahırlar inşa edilerek yaşlıların büyükbaş hayvan yetiştiriciliğinin devamı sağlanabilir ve iş yükü azalacağından hayvan sayısı artabilir. Modern ahırlarda yazın hayvanlarını otlatıp kışın işsiz kalan çobanlara kış aylarında istihdam sağlanabilir. Her köye birer büyük modern ahır yapılarak hayvancılığın gelişimi sağlanmış olur. Aynı zamanda hayvan bakıcıları (çoban) iş hukukuna uygun çalışma şartlarını elde etmiş olurlar.

Finansal Destek: Yazarlar bu çalışma için finansal destek almamışlardır. 


\section{Kaynakça/References}

Ak, M. (2012). 19. Yüzyılda Teke Yöresi Yörüklerinin Sosyo-Ekonomik Durumu. Doktora Tezi, Akdeniz Üniversitesi, Sosyal Bilimler Enstitüsü.

Arslan, D. A. (2003). Bir Köy Sosyolojisi Çalışması: Kavaközü Köyü'nün Sosyo-Ekonomik Yapısı ve Sorunları, Osmangazi Üniversitesi Sosyal Bilimler Dergisi, 4(1), 1-26.

Arslan, D. A. (1992). Kalkınma Dönemecinde Kavaközü, Konya, Selçuk Üniversitesi Lisans Tezi.

Azizova, E. (2007). Hz Peygamber Döneminde Çalışma Hayatı ve Meslekler. Doktora Tezi, Marmara Üniversitesi, Sosyal Bilimler Enstitüsü.

Çağlar, S. (1969), Toplum Kalkınmasında Başarı Yolları, Ankara: Güven Matbaası.

Çetinkaya, E. ve Diğerleri. (2010), Genç İşsizliğinin Teorik Açıklamaları, Sosyal Siyaset Konferasnlarl Dergisi, 58, 45-57.

Çoban, V. (2015). Türk Halk Kültüründe Çobanlık. Yüksek Lisans Tezi, Fırat Üniversitesi, Sosyal Bilimler Enstitüsü.

Fidan, F. ve Fidecioğlu, A. (2010), Kutsallık ile tutsaklık arasında bir meslek öğretmenlik: Sorunlar, yaklaşımlar ve beklentiler. Adıyaman Üniversitesi Sosyal Bilimler Enstitüsü Dergisi 3(5).

Geniş, Ş. (2009). Gaziantep kırsalında sanayileşme ve toplumsal değişim: Dülük Köyü örneği. Gaziantep Üniversitesi Sosyal Bilimler Dergisi, 8(1), 21-48.

İleri, C. (2011). Eskişehir'de Çobanlık, Çoban Kitabı, İstanbul.

Kıray, M. (1964). Ereğli: Ăgır Sanayiden Önce Bir Sahil Kasabası. İstanbul: DPT Yayınları.

Koruk, İ. (2010). İhmal edilen bir grup: göçebe mevsimlik tarım işçileri. Mesleki Sağlık ve Güvenlik Dergisi, 10(38), 18-22.

Lordoğlu, K. ve Nilay, E. (2014). Batı Karadeniz bölgesinde mevsimlik gezici tarım işçiliğinde çalışan çocuklar üzerine sınırlı bir araştırma. Çalışma ve Toplum Dergisi, 2, 115-134.

Naskali, E, G. (2011), Çoban Kitabı, İstanbul: Bayrak Matbaası.

Ögel, B. (1985). Türk Kültür Tarihine Giriş I, Ankara: Kültür Turizm Bakanlığı Yayınları.

Özbekmezci, Ş. ve Sahil, S. (2004). Sahil mevsimlik tarım işçilerinin sosyal, ekonomik ve barınma sorunlarının analizi. Gazi Üniversitesi Mühendislik Mimarlık Fakültesi Dergisi, 19(3), 261-274.

Şakar, M. (2018). İ̧̧ Hukuku ve Sosyal Güvenlik Hukuku, 11. Baskı, İstanbul: Beta Basım Yayın Dağıtım. 
